\title{
Assessing Grocery Store Attraction via Cross-Shopping Linkages
}

\author{
Charles D. Bodkin (Corresponding author) \\ Dept. of Marketing, University of North Carolina at Charlotte \\ 9201 University City Blvd., Charlotte, NC 28223 \\ E-mail: cbodkin@uncc.edu \\ Ellen Sewell \\ Dept. of Economics, University of North Carolina at Charlotte \\ 9201 University City Blvd., Charlotte, NC 28223 \\ E-mail: esewell@uncc.edu
}

Received: October 26, 2012 Accepted: November, 14, 2012

doi:10.5296/ber.v2i2.2572

URL: http://dx.doi.org/10.5296/ber.v2i2.2572

\begin{abstract}
The present study is unique in its approach to assessing the value of cross-shopping by categorizing stores as either a customer attraction or a customer sharing store. Previous research has used consumer perceptions of store qualities (i.e., service quality, price, store brands) to develop consumer profiles of cross-shoppers. These profiles are subsequently linked to specific retail formats. In the current study results from a mail survey of grocery shoppers located in Charlotte, NC are used to measure a store's attraction/sharing ratio. The study found that infrequent shoppers perceive attraction stores to have greater service quality, but these perceptions change as shopping frequency increases. The findings imply that a grocery store owner should focus on reliability, responsiveness, assurance, and empathy to attract cross-shoppers away from the competition.
\end{abstract}

Keywords: Cross-shopping, Grocery stores, Service Quality

\section{Introduction}

With the realization that technology is changing consumer behaviors, retailers are 
increasingly concerned about maintaining consumer loyalty and attracting customers away from the competition. In today's market, technology is increasing the likelihood of consumer cross-shopping. Through the use of smart phones, consumers can search multiple stores for price and either make the purchase online or travel to another store to make a purchase. Recently Lesonsky (2012) reported on a study by Prosper Mobile Insights which found that $40 \%$ of their respondents, after learning of lower prices via their mobile device, left the store they were currently in to go to a competitor's store. But price is only one of the evaluative criteria used by consumers when making a purchase. Retailers have found that customer service and product quality may also provide a means to reduce cross-shopping behavior and increase store loyalty (Lesonsky, 2012).

The marketing literature has addressed retail patronage and focused on store selection criteria such as convenience, accessibility, and price (Ruoh-Nan \& Eckman, 2009; Aggrawal, Manjrekar, \& Aggrewal, 2011; Zameer \& Mukherjee, 2011). Like retail patronage, cross-shopping behavior addresses issues related to store selection, but cross-shopping behavior also implies consumer evaluation of multiple stores. Since a wide range of store formats exist (i.e., grocery stores, discount stores, supercenters, off-price stores) it is important to address the degree of similarity among store formats selected by consumers for cross-shopping. Inter-type competition occurs when consumers' cross-shop across various types of store formats (a grocery store and a discount department store) while intra-type competition occurs when consumers cross-shop similar store formats (e.g., only grocery stores or only discount department stores). In intra-type competition, lower prices can be an important part of a store's strategy, but can lead to lower profits. On the other hand, the use of service and product branding provides stores an opportunity to maintain loyalty while retaining profitability.

Previous cross-shopping research has focused on consumer characteristics of cross-shoppers in both inter- and intra-type markets. The majority of this research has been consumer centric meaning research has focused on differences between consumer segments (i.e, cross-shoppers versus non-cross-shoppers). For example, previous cross-shopping research has examined demographic variables such as gender, age, and income (Cort \& Dominguez, 1977; Hirschman, 1979; and Sullivan \& Savitt, 1997). For a store owner this information can be useful, but provides limited insights into changes the store could make to attract cross-shoppers from other stores or reduce the percentage of shoppers they share with their competition.

Current cross-shopping research has examined antecedents of cross-shopping behavior by studying consumer preferences and demographics which are used to profile a cross-shopper (Carpenter \& Balija, 2010). In previous research the premise has been that consumer preferences can be mapped to store formats (Davies, 1992). These preference profiles provide marketers a means to identify differences among market segments and subsequently associate the market segments with specific store formats. The current study takes a unique approach to better understand the strategic implications of cross-shopping behavior. Using cross-shopping data this study attempts to determine the strength of a store to attract customers away from its competitors. Stores that attract shoppers away from their competitors' stores are providing 
greater perceived value. Understanding the differences between stores that can attract cross-shoppers away from a competitor versus a store that "shares" their customers with the competition would be of great importance in the development of the retailer's strategy.

\section{Theoretical Foundation}

From the moment a store's competitor opens in its trading area, consumers can choose where they will spend their dollars. With competition it becomes critical for the retailer to understand the differences between consumers who are store loyal and consumers who will cross-shop. Attracting the cross-shopper market can provide retailers a strategic advantage to increase their market share. The concept of cross-shopping has been addressed in the literature from multiple perspectives such as store switching behavior (Dholakia \& Uusitalo, 2002; Findlay and Sparks, 2008), store choice behavior (Sands, Oppewal, \& Beverland, 2009; Hsieh \& Steigert, 2012), multi-store purchasing (Mahajan, 1988), even consumer promiscuity (McGoldrick \& Andre, 1995) The current study uses Cort and Domiguez's (1977) definition of cross-shopping which states that cross-shopping occurs "when a single consumer patronizes multiple types of retail outlets which carry the same broad lines of merchandise" (p. 187).

In the marketing literature, the foundation for cross-shopping research is derived from Hirschman's (1978) Theory of Retail Market Structure and the Principle of Natural Dominance. The Principle of Natural Dominance is based on competition among retail formats and has two tenets. First, retailers can be grouped by their price, quality, and merchandising strategies. Second, intra-type competition is greater than inter-type competition. These tenets provide a means to categorize previous cross-shopping research.

Previous research has focused on the antecedents of cross-shopping behavior. A review of the literature identified consumer characteristics (e.g., gender, age, income, household size, education, and time pressure) and retail mix strategies as the predominant antecedents used to enhance our understanding of cross-shopping behavior. Using type of competition (i.e., inter-, intra-) and antecedents of cross-shopping behavior (i.e., consumer characteristics, retailer characteristics) a taxonomy of four categories showing how consumer characteristics and type of competition affect cross-shopping behavior was developed (see Figure 1).

\begin{tabular}{|l|l|l|}
\hline & Inter-type & Intra-type \\
\hline & Ingene (1983) & Cort \& Dominguez (1977) \\
\hline Consumer & McGoldrick \& Andre (1995) & Hirschman (1979) \\
\hline Characteristics & Carpenter \& Moore (2006) & Leszcyc \& Timmermans (2001) \\
\hline & Skallerud et al. (2009) & \\
\hline Retailer & Bucklin \& Lattin (1992) & Cassill et al. (1993) \\
\hline Characteristics & $\begin{array}{l}\text { Fox et al. (2004) } \\
\text { Seock (2009) }\end{array}$ & $\begin{array}{l}\text { Cassill \& Williamson (1994) } \\
\text { Rhee \& Bell (2002) }\end{array}$ \\
\hline
\end{tabular}

Figure 1. A taxonomy of cross-shopping behavior literature.

\subsection{Consumer Characteristics / Inter-type Competition}


Identifying sociodemographic antecedents of cross-shopping behavior in inter-type competition provides retailers with a broad understanding of market segments. Previous research has found that income (Carpenter \& Moore, 2006), time (Carpenter \& Moore, 2006; Skallerud, Korneliussen, \& Olsen, 2009), and distance to the store (McGoldrick \& Andre, 1995; Bodkin \& Lord, 1997) can heavily influence cross-shopping behavior. In addition a variety of retail formats has been studied. Carpenter and Moore (2006) created demographic profiles of consumers who frequent traditional supermarkets, internet grocers, specialty grocers, supercenters, and warehouse clubs. Skallerud et al. (2009) found a consumer's impulse buying tendency is negatively related to supermarket patronage but positively related to specialty store (i.e., seafood and meat stores) patronage.

\subsection{Retailer Characteristics / Inter-type Competition}

While retailers can identify and respond to consumer demographics and preferences, they have greater control over store characteristics. By creating a unique and competitive strategy retailers can enhance loyalty and reduce consumer cross-shopping behavior. Previous research has examined retailer characteristics such as store location (Bucklin \& Lattin, 1992), product assortment and promotion (Fox, Montgomery, \& Lodish, 2004), and store services (Ingene, 1983). In addition, Corstjens and Lal (2000) found that private label brands can be effective in creating store differentiation and consumer loyalty. While research classified in this category can provide retailers with insights into strategy development, findings from these studies will also be generalizable across a wide variety of store formats.

\subsection{Consumer Characteristics / Intra-type Competition}

The second tenet of The Principle of Natural Dominance is that intra-type competition is greater than inter-type competition. In a follow-up to her seminal research, Hirschman (1979) examined more than 25 consumer characteristics of department store shoppers. She found that traditional department store customers come from a higher social class and possess greater education compared to customers who frequent national and discount department store. Similarly, using panel data Leszczyc and Timmermans (2001) developed consumer profiles for grocery store shoppers. They examined differences in shopping behavior based on sociodemographic variables such as income, hours worked, and household size and concluded that sociodemographic variables would be useful for store managers to target cross-shoppers.

\subsection{Retailer characteristics / intra-type competition}

Of particular interest to the current study are retailer characteristics used to examine cross-shopping behavior within specific retailing formats (i.e., intra-type competition). Hirschman (1978) emphasized the need for retailers to recognize that intra-type retail competition would be more intense than inter-type competition. As competition increases among stores operating with similar formats it becomes imperative for the retailer to find new strategies for differentiation. Previous research has examined variables such as pricing strategies (Rhee \& Bell, 2002), store image (Cort \& Dominguez, 1977), product brand dimensions (Cassill, Williamson, McEnally, \& Thomas, 1993), store services (Cassill \& 
Williamson, 1994), and store location (Davies, 1992).

Of the four research categories discussed the current study focuses on the latter (i.e., retailer characteristics / intra-type competition). Specifically, it has been suggested in the literature that offering private label brands (Corstjens \& Lal, 2000) and service quality (Huddleston, Whipple, Mattick, \& So, 2009) can influence store loyalty and cross-shopping behavior. Following is a discussion of the use of private labels and service quality to limit cross-shopping behavior.

\subsection{Private Label Branding}

Retailers rely on private label branded products to differentiate themselves from the competition and extensive research has provided mixed results regarding the role of private label brands in creating store loyalty. Indeed, Ngobo (2011) and Fontenelle and Pereira (1996) found that offering private label brands can be a key strategy to building store loyalty. Richardson and Jain (1996) proposed a model of store brand proneness and found that store brand quality and value influence consumer attitudes toward store brands. Bellizzi, Krueckeberg, Hamilton, \& Martin (1981) and Ailawadi, Pauwels, \& Steenkamp (2008) found a weak link between offering private label brands and store loyalty, and Corstjens and Lal (2000) found that offering private label brands can reduce consumer cross-shopping.

\subsection{Services}

Quality service is an important attribute in the consumer decision-making process for store selection. Service quality affects store loyalty via influence on store image and customer satisfaction (Nesset, Nervik, \& Helgesen, 2011). Retailers have long recognized that one way to differentiate their stores is to offer high-quality service. In the grocery industry, the service component of store operations can be a key source of differentiation (Homburg, Hoyer, \& Fassnacht, 2002). While service quality has been researched in light of developing consumer loyalty, little research has been conducted regarding the influence of service quality on cross-shoppers. Previous cross-shopping research has addressed service related to sales associates (Hirschman, 1979; Värlander \& Yakhlef, 2008), gift wrapping, and clothing alterations (Cassill \& Williamson, 1994) and specialty retailers such as delicatessens (Ingene, 1983).

\section{Perspectives on Cross-shopping Behavior}

The cross-shopping literature suggests there are two perspectives by which cross-shopping behavior can be studied. The most common perspective is consumer oriented. Consumers are asked to identify which stores they patronize (Cort \& Dominguez, 1977) and the frequency of visits (Skallerud et al., 2009). Measurements of switching and patronage ratios are then developed to identify a consumer's likelihood of cross-shopping. A second perspective takes a store perspective and identifies the store's likelihood of being cross-shopped by consumers. This approach is referenced in the research by Morgansky (1997), Lord and Bodkin (1996), and Bodkin and Lord (1997).

Morgansky (1997) examined patronage behaviors across (inter-type) retail channels. Of 
particular interest to the current study is the discussion of channel push and pull which describes cross-shopping as the extent to which a "channel is able to pull in or attract customers from each of the other channels" (p. 214). Morgansky (1997) measured the degree to which retail formats are more likely to push (i.e., share) customers to other retail formats or the degree to which one retail format can pull (i.e, attract) customers from other retail formats. It was found that supercentres share $95 \%$ of their customers with supermarkets and attract $77 \%$ of their customers from limited-line discount stores.

Research conducted by Lord and Bodkin (1996) and Bodkin and Lord (1997) also used the store perspective of cross-shopping across (inter-type) retail formats. In their study of retail stores within a shopping center, they developed sender (i.e., sharing) and receiver (i.e., attraction) ratios which were used as the basis for identifying stores that were more likely to demonstrate cross-shopping behavior. They found cross-shopping was driven by distance between stores, store compatibility, and store size.

While previous research (Lord \& Bodkin, 1996; Bodkin \& Lord, 1997; and Morgansky, 1997) demonstrated that store linkages provide a measure of cross-shopping behavior, none of the previous research examined consumers' perceptions of private label brands and service quality associated with stores that are more likely to share customers (i.e., being a push or sender store) versus stores that are more likely to receive customers (i.e., being a pull or receiver store).

\section{Research Problem}

This study will provide a better understanding of the retail market structure (Hirschman, 1978) for grocery stores (intra-type) by providing an assessment of the cross-shopping linkages. While beliefs regarding private label brands and service quality have been identified as key factors of store loyalty; their influence on cross-shopping as a store characteristic has not been addressed in the literature. Once cross-shopping patterns have been identified, this study will examine consumer perceptions associated with the store characteristic of cross-shopping.

\section{Methodology}

Data were collected from a random sample of grocery shoppers in Charlotte, NC. A mail survey was sent to the respondents along with an offer to participate in an opportunity to win fifty dollars. For the present study one thousand surveys were mailed and 169 (16.9\%) usable surveys were returned.

Demographics were gathered and include gender, age, number of people living at home, approximate income, education level, and race (see Table 1). Respondents tended to be female $(65 \%)$. Average age is 45 years old. On average respondents reported two or three people living at home, including themselves. Approximately $75 \%$ of respondents earned incomes less than $\$ 60,000,44 \%$ had some college education, and the majority of respondents classified themselves as Caucasian (86\%). Approximately $64 \%$ of respondents identified a second store that they shop at least once per month. These respondents formed the basis for the cross-shopping analysis. 
Table 1. Respondents' Profile

\begin{tabular}{|l|c|c|}
\hline & $\mathrm{N}$ & $\%$ \\
\hline Gender & & \\
\hline Female & 110 & 65.1 \\
\hline Male & 59 & 34.9 \\
\hline & 169 & 100.0 \\
\hline Household size & & \\
\hline 1 & 39 & 23.2 \\
\hline 2 & 76 & 45.2 \\
\hline 3 & 16 & 9.5 \\
\hline 4 & 24 & 14.3 \\
\hline $5+$ & 13 & 7.7 \\
\hline & 168 & 100.0 \\
\hline Income & & \\
\hline \$20,000 or less & 21 & 13.2 \\
\hline \$20,001 to \$40,000 & 47 & 29.6 \\
\hline \$40,001 to \$60,000 & 52 & 32.7 \\
\hline \$60,001 to \$80,000 & 24 & 15.1 \\
\hline \$80,001 or more & 15 & 9.4 \\
\hline & 159 & 100.0 \\
\hline Education & & \\
\hline Less than high school & 2 & 1.2 \\
\hline Completed high school & 18 & 10.7 \\
\hline Some college & 53 & 31.5 \\
\hline Completed college & 60 & 35.7 \\
\hline More than college & 35 & 20.8 \\
\hline & 168 & 100.0 \\
\hline Race & & \\
\hline African American & 19 & 12.4 \\
\hline White/Caucasian & 134 & 87.6 \\
\hline & 153 & 100.0 \\
\hline
\end{tabular}

The questionnaire consisted of twenty-four items related to service quality and eight items related to consumers' perceptions of private label brand quality and value. A review of the service quality (Parasuraman, Zeithaml, \& Berry, 1988; Baker, Grewal, \& Parasuraman, 1994; Dabholkar, Thorpe, \& Rentz, 1996) and private label literature (Richardson \& Jain, 1996; Burton, Lichtenstein, Netemeyer, \& Garretson, 1998; Garretson, Fisher, \& Burton, 2002; Ailawadi et al., 2008) provided the basis for items used in the study. Respondents were asked to think about "the grocery store they shop at most often" when completing the survey. A seven-point likert scale (i.e., strongly disagree/strongly agree) accompanied each statement. At the end of the survey, respondents were asked to identify their primary and secondary grocery stores and their frequency of shopping. 
Cronbach's alpha was used to measure the construct reliabilities. Results of the analysis indicate that all of the constructs were reliable. The coefficient alpha's ranged from .83 for service reliability to .91 for tangibility and private label quality. See Appendix A for examples of survey questions, number of items per construct, and reliability measures.

The survey data will provide a number of useful insights related to cross-shopping patterns within the grocery store market. The degree to which the stores are linked to each other store will be determined by calculating the proportion of a store's shoppers who visited at least one other store. For example, if store A has 100 shoppers and 80 of its shoppers visited another store (e.g., Stores B, C, or D) then we could say that $80 \%$ of store A shoppers are cross-shoppers. In order to assess intra-type competition (i.e., cross-shopping linkages), the proportion of Store A shoppers who also shopped at each of the other stores will be computed. For example, $20 \%$ of Store A shoppers who identified Store A as their primary store may have shopped at Store B, 30\% of Store A shoppers may have shopped at Store C, and 50\% of Store A shoppers may have shopped at Store D. The latter information when compiled for all stores will produce a cross-shopping matrix which displays the strength of the cross-shopping linkages between all possible pairs of stores in the center.

Cross-shopping patterns are also examined to determine if there are clusters of stores with strong cross-shopping linkages. Each store's status in the cross-shopping linkages can be further revealed by computing both its attraction (i.e., receiving, pulling) and sharing (i.e., sending, pushing) percentages and the resulting attraction/sharing ratio. A store's attraction percentage is the mean percentage of primary shoppers that come from other stores. For example, if $50 \%$ of shoppers whose primary store was B shopped at Store A, 30\% of shoppers whose primary store was C shopped at Store A, and 20\% of shoppers whose primary store was D shopped at Store A, then Store A's attraction percentage would be $33.3 \%$ (i.e., $(50+30+20) / 3)$. This number is a measure of the importance of the store in generating shopping linkages. A store's sharing percentage is the mean percentage of shoppers that shop at the other grocery stores and is an indicator of dependency between stores. For example, if 25\% of shoppers whose primary store was A shopped at Store B, 20\% of shoppers whose primary store was A shopped at Store C, and 15\% of shoppers whose primary store was A shopped at Store D, then Store A's sharing ratio would be $20 \%$ (i.e., $(25+20+15 / 3)$. By creating an attraction/sharing ratio it is possible to examine the attraction level of a store relative to other stores in the market. Finally, the effects of service quality and the perceived quality and value of private label brands on the strength of a store's cross-shopping attribute will be addressed using multivariate analysis of variance.

\section{Results}

\subsection{Amount of Cross-shopping}

The degree of cross-shopping can be assessed by examining consumer and store characteristics. Consumer characteristics include the number of stores shopped and frequency of shopping. On average respondents visit a grocery store 2.0 times per month, see Table 2 . 


\section{Macrothink}

Business and Economic Research

ISSN 2162-4860

2012, Vol. 2, No. 2

Table 2. Number of Stores Visited

\begin{tabular}{|c|c|c|c|c|c|c|c|c|}
\hline \multirow[t]{2}{*}{$\begin{array}{l}\text { Primary } \\
\text { Store }\end{array}$} & \multirow[t]{2}{*}{$\begin{array}{c}\text { Number of } \\
\text { shoppers }\end{array}$} & \multicolumn{5}{|c|}{$\begin{array}{l}\text { Number of stores shopped } \\
\text { monthly }\end{array}$} & \multirow[t]{2}{*}{$\begin{array}{l}\text { Total number of } \\
\text { visits per month }\end{array}$} & \multirow[t]{2}{*}{$\begin{array}{l}\text { Average number of } \\
\text { visits per month }\end{array}$} \\
\hline & & 1 & 2 & 3 & 4 & 5 & & \\
\hline $\mathrm{Bi} / \mathrm{Lo}$ & 22 & 6 & 10 & 4 & 2 & 0 & 46 & 2.1 \\
\hline Food Lion & 28 & 8 & 14 & 4 & 1 & 1 & 57 & 2.0 \\
\hline Hannaford & 6 & 1 & 4 & 1 & 0 & 0 & 12 & 2.0 \\
\hline $\begin{array}{l}\text { Harris } \\
\text { Teeter }\end{array}$ & 78 & 24 & 38 & 15 & 0 & 1 & 150 & 1.9 \\
\hline $\begin{array}{l}\text { Super } \\
\text { Kmart }\end{array}$ & 2 & 0 & 1 & 1 & 0 & 0 & 5 & 2.5 \\
\hline Winn Dixie & 11 & 2 & 5 & 4 & 0 & 0 & 24 & 2.2 \\
\hline Other & 4 & 1 & 1 & 2 & 0 & 0 & 9 & 2.3 \\
\hline Total & 151 & 42 & 73 & 31 & 3 & 2 & 303 & 2.0 \\
\hline
\end{tabular}

The frequency of shopping trips was examined on a bi-weekly, weekly, and 2 or more times per week. Approximately 14\% were bi-weekly shoppers, $42 \%$ shopped weekly, and $44 \%$ shopped two or more times per week (see Table 3). Cross-shopping can also be assessed from the store's perspective by examining the proportion of cross-shoppers of each store (see Table 4). On average approximately $79 \%$ of respondents are cross-shoppers. Overall, the data support cross-shopping patterns within the grocery market, therefore, the data are acceptable for creating a cross-shopping table.

Table 3. Cross-shopping frequency

\begin{tabular}{|l|c|c|c|c|}
\hline $\begin{array}{c}\text { Primary } \\
\text { Store }\end{array}$ & Number of shoppers & $\begin{array}{c}1 \text { time } \\
\text { every 2 weeks }\end{array}$ & $\begin{array}{c}1 \text { time } \\
\text { per week }\end{array}$ & $\begin{array}{c}\text { 2+ times } \\
\text { per week }\end{array}$ \\
\hline Bi/Lo & 22 & 4 & 11 & 7 \\
\hline Food Lion & 28 & 4 & 11 & 13 \\
\hline Hannaford & 6 & 2 & 2 & 2 \\
\hline Harris Teeter & 78 & 6 & 32 & 40 \\
\hline Super Kmart & 2 & 1 & 0 & 1 \\
\hline Winn Dixie & 11 & 2 & 3 & 6 \\
\hline Other & 4 & 2 & 2 & 0 \\
\hline Total & 151 & 21 & 61 & 69 \\
\hline & & & & \\
\hline Average $(\%)$ & & 13.9 & 40.4 & 45.7 \\
\hline
\end{tabular}


Table 4. Proportion of cross-shoppers per store

\begin{tabular}{|l|c|c|c|}
\hline & Number of shoppers & Number of cross-shoppers & Percentage of cross-shoppers \\
\hline & & & \\
\hline Bi/Lo & 22 & 16 & 72.7 \\
\hline Food Lion & 28 & 20 & 71.4 \\
\hline Hannaford & 6 & 5 & 83.3 \\
\hline Harris Teeter & 78 & 54 & 69.2 \\
\hline Super Kmart & 2 & 2 & 100 \\
\hline Winn Dixie & 11 & 9 & 81.8 \\
\hline Other & 4 & 3 & 75 \\
\hline Total & 151 & 109 & 79.1 \\
\hline
\end{tabular}

\subsection{Cross-shopping Analysis}

\subsubsection{Cross-shopping Linkages.}

The cross-shopping analysis was undertaken by creating a matrix that shows the percentage of a store's primary shoppers that patronize each of the other stores, see Table 5.

Table 5. Cross-shopping matrix

\begin{tabular}{|c|c|c|c|c|c|c|}
\hline & \multicolumn{5}{|c|}{ Who also shopped at (\%) } & \\
\hline $\begin{array}{c}\text { Shoppers at: } \\
\text { (primary store) }\end{array}$ & Bi/Lo & Food Lion & Hannaford & Harris Teeter & Winn Dixie & Sharing \% \\
\hline Bi/Lo & & 44.8 & 3.4 & 37.9 & 6.9 & 23.3 \\
\hline Food Lion & 31.0 & & 4.8 & 35.7 & 23.8 & 23.8 \\
\hline Hannaford & 5.3 & 10.5 & & 73.7 & 10.5 & 25.0 \\
\hline Harris Teeter & 17.5 & 23.8 & 22.2 & & 17.5 & 20.3 \\
\hline Winn Dixie & 7.7 & 38.5 & 7.7 & 42.3 & & 24.1 \\
\hline Attraction \% & 15.4 & 29.4 & 9.5 & 47.4 & 14.7 & \\
\hline
\end{tabular}

At this point in the analyses Super K-mart was removed due to small sample size. In addition, the "other" category was also removed from further analyses. These percentages show the cross-shopping linkages between each store with every other store. Since the percentage of shoppers who chose Harris Teeter as their primary store and also shopped at Food Lion is not the same as the percentage of shoppers who chose Food Lion as their primary store and also shop at Harris Teeter, the cross-shopping matrix does not reflect the same information on either side of the diagonal. For example, the percentage of Bi/Lo shoppers who shopped at Food Lion was $44.8 \%$ while the percentage of Food Lion shoppers that shopped at Bi/Lo was $31.0 \%$. The strength of the grocery store as a preferred store can be identified by examining the columns in Table 5. It appears that Harris Teeter stores attract over 35\% of cross-shoppers from each of the other stores and Food Lion stores attract over 20\% of cross-shoppers from three of the five stores. Further evidence of the store's degree of attraction can be identified 
by examining the strengths of the twenty possible cross-shopping linkages. A review of the ten most important cross-shopping linkages indicates that Harris Teeter attracts customers from all of the other stores and Food Lion attracts customers from three of the four other stores, see Table 6. Bi/Lo and Winn Dixie are attract customers only from Food Lion shoppers and Hannaford attracts customers from Harris Teeter.

Table 6. Cross-shopping linkages

\begin{tabular}{|c|c|c|}
\hline From & To & $\begin{array}{c}\text { Amount of } \\
\text { Cross-shopping } \\
(\%)\end{array}$ \\
\hline Hannaford & Harris Teeter & 73.7 \\
\hline Bi/Lo & Food Lion & 44.8 \\
\hline Winn Dixie & Harris Teeter & 42.3 \\
\hline Winn Dixie & Food Lion & 38.5 \\
\hline Bi/Lo & Harris Teeter & 37.9 \\
\hline Food Lion & Harris Teeter & 35.7 \\
\hline Food Lion & Bi/Lo & 31.0 \\
\hline Food Lion & Winn Dixie & 23.8 \\
\hline Harris Teeter & Food Lion & 23.8 \\
\hline Harris Teeter & Hannaford & 22.2 \\
\hline
\end{tabular}

\subsubsection{Attraction and Sharing}

Using the means of the cross-shopping matrix, measures of a store's level of attraction and sharing were developed, see Table 7.

Table 7. Cross-shopping attraction/sharing ratio

\begin{tabular}{|l|c|c|c|}
\hline & $\begin{array}{c}\text { Attraction } \\
\text { Mean } \\
\%\end{array}$ & $\begin{array}{c}\text { Sharing Mean } \\
\%\end{array}$ & Attraction / Sharing Ratio \\
\hline Bi/Lo & 15.4 & 23.3 & 0.66 \\
\hline Food Lion & 29.4 & 23.8 & 1.24 \\
\hline Hannaford & 9.5 & 25.0 & 0.38 \\
\hline Harris Teeter & 47.4 & 20.3 & 2.33 \\
\hline Winn Dixie & 14.7 & 24.1 & 0.61 \\
\hline
\end{tabular}

Attraction was measured by calculating the column means for each of the stores in the cross-shopping matrix. This calculation is similar to the research on receiving (i.e., attraction) and sending (i.e., sharing) conducted by Lord and Bodkin (1996) and Bodkin and Lord (1997). A lower attraction/sharing ratio (i.e., less than 1.0) indicates that the store's cross-shoppers are more likely to shop at a secondary store choice.

The ratio of attraction/sharing provides a measure of the store's ability to attract cross-shoppers away from the competition. A higher attraction/sharing ratio (i.e., greater than 1.0) implies that the store attracts more shoppers than it shares, suggesting that it is more 
likely to be a market leader. The results indicate Harris Teeter and Food Lion have the highest attraction/sharing ratios at 2.35 and 1.24, respectively indicating they are more likely to attract shoppers from their competitors. It is interesting to note that Harris Teeter's attraction/sharing ratio is almost twice that of Food Lion. As noted earlier, only 53\% of Harris Teeter shoppers indicated they were cross-shoppers providing further support for the higher attraction/sharing ratio found in this analysis. Bi/Lo, Winn Dixie, and Hannaford have attraction/sharing ratios less than 1.0 (i.e., .66, .61, and .38, respectively) indicating they are more likely to share their customers with their competition. Both Hannaford and Winn Dixie had over $90 \%$ of their customers indicate they were cross-shoppers. While Bi/Lo had fewer cross-shoppers compared to Food Lion (see Table 4) they also attracted fewer shoppers from other stores resulting in their lower attraction/sharing ratio.

Based on the findings of the attraction/sharing ratios, stores were grouped into two categories. Stores having attraction/sharing ratios greater than 1.0 were categorized as attraction stores (i.e., Harris Teeter and Food Lion). Stores having attraction/sharing ratios less than 1.0 were categorized as sharing stores (i.e., Bi/Lo, Winn Dixie, and Hannaford).

\subsection{Cross-shopping Model}

\subsubsection{Dependent variables}

In order to test the influence of service quality and use of private label brands on the attraction/sharing concept, the reliability of the measures were assessed using Cronbach's alpha (see Appendix A). The SERVQUAL scale has five dimensions which include tangibiles (e.g., physical aspects of the store and personnel), reliability (e.g., dependability and accuracy), responsiveness (e.g., prompt service), assurance (e.g., employee knowledge and trustworthiness), and empathy (e.g., customer caring) (Parasuraman et al., 1988). Parasuraman, et al. (1988) found reliability coefficients for the five dimensions ranged from .72 to .86 . The current study identified similar reliability coefficients (tangibles $=.91$; reliability $=.83$; responsiveness $=.87$; assurance $=.90$; and empathy $=.86$ ). In addition, questions regarding consumer perceptions of the quality and value of store brands were included in the study and were factor analyzed resulting in two dimensions. The two dimensions included satisfaction with private label brands and a perception that private label brands provide value due to their lower cost. The reliability coefficients for the constructs "private label satisfaction" and "private label value" were .91 and .84, respectively.

\subsubsection{Demographic analysis}

Prior to addressing the relationships between attraction/sharing with service quality and private label perceptions, consumer demographics were examined. Demographics gathered in the current study include: gender, age, number of persons living at home, education, income, and race. Initially crosstab analysis was used to determine whether consumer demographics accounted for differences between attraction and sharing stores. The results indicate that race was significantly $(\mathrm{p}<.05)$ related to differences in the store characteristic of attraction and sharing. African American respondents were proportionately more likely to shop at sharing stores while White/Caucasian respondents were proportionately more likely to shop at 
attraction stores. Subsequently a multivariate analysis of variance was used to examine the relationship between consumer demographics and the dependent variables (i.e., service quality dimensions, private label quality, and private label value). The results found no significant differences $(\mathrm{p}<.05)$ indicating that consumer demographics are not influencing consumers' perceptions of the service quality dimensions, private label quality, or private label value.

\subsubsection{Attraction/Sharing model}

A multivariate analysis of variance was used to model the influence of shopping frequency and the store's attraction/sharing ratio on consumers' perceptions of service quality dimensions, private label quality, and private label value. The findings indicate a significant $(\mathrm{p}=.043)$ interaction exists between shopping frequency and the store's attraction/sharing ratio for four of the five service quality dimensions (see Table 8 ). The significant service quality dimensions include, reliability $(\mathrm{p}=.048)$, responsiveness $(\mathrm{p}=.013)$, assurance $(\mathrm{p}=.043)$, and empathy $(\mathrm{p}=.021)$. No significant relationship was found with the service quality dimension of tangibles, private label quality, or private label value (see Table 9).

Table 8. MANOVA results for service quality by shopping frequency

\begin{tabular}{|c|c|c|c|}
\hline & & Attraction & Sharing \\
\hline \multirow{3}{*}{ Tangibility } & Once every two weeks & 5.83 & 5.61 \\
\hline & One time per week & 5.95 & 5.29 \\
\hline & More than twice per week & 5.79 & 6.31 \\
\hline \multirow{3}{*}{ Reliability* } & Once every two weeks & 5.63 & 5.19 \\
\hline & One time per week & 5.27 & 4.82 \\
\hline & More than twice per week & 5.17 & 6.06 \\
\hline \multirow{3}{*}{ Responsiveness* } & Once every two weeks & 6.38 & 4.77 \\
\hline & One time per week & 5.56 & 4.91 \\
\hline & More than twice per week & 5.28 & 6.11 \\
\hline \multirow{3}{*}{ Assurance* } & Once every two weeks & 6.25 & 5.00 \\
\hline & One time per week & 5.48 & 5.20 \\
\hline & More than twice per week & 5.24 & 6.28 \\
\hline \multirow{3}{*}{ Empathy* } & Once every two weeks & 6.13 & 5.00 \\
\hline & One time per week & 5.65 & 4.96 \\
\hline & More than twice per week & 5.42 & 6.22 \\
\hline
\end{tabular}

$* \mathrm{p}<.05$ 
Table 9. MANOVA results for private label by shopping frequency

\begin{tabular}{|l|l|c|c|}
\hline & & Attraction & Sharing \\
\hline \multirow{4}{*}{ Private labels are good } & Once every two weeks & 4.88 & 3.81 \\
\cline { 2 - 4 } & One time per week & 4.30 & 4.18 \\
\cline { 2 - 4 } & More than twice per week & 5.01 & 4.11 \\
\hline \multirow{3}{*}{ Private labels have value } & & & \\
\cline { 2 - 4 } & Once every two weeks & 6.00 & 5.38 \\
\cline { 2 - 4 } & One time per week & 5.54 & 5.09 \\
\hline & More than twice per week & 5.18 & 5.39 \\
\hline
\end{tabular}

$* \mathrm{p}<.05$

The multivariate analysis of variance found that infrequent shoppers (i.e., shop less than one time per week) perceive attraction stores possess greater reliability, responsiveness, assurance, and empathy, but the opposite was found for frequent shoppers. Frequent shoppers (i.e., shop more than twice per week) perceive sharing stores to possess greater reliability, responsiveness, assurance, and empathy (see Figures 2 to 5).

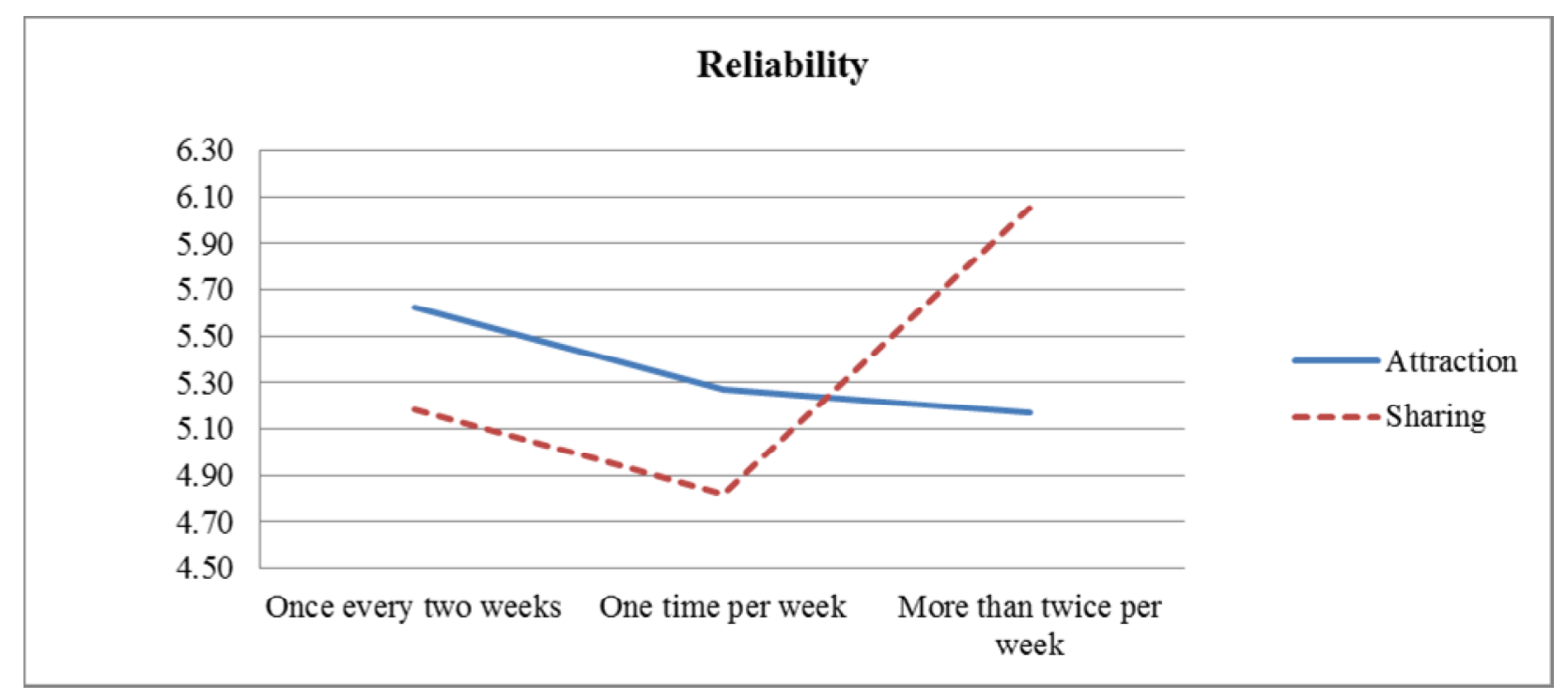

Figure 2. Differences between attraction and sharing stores: Reliability 


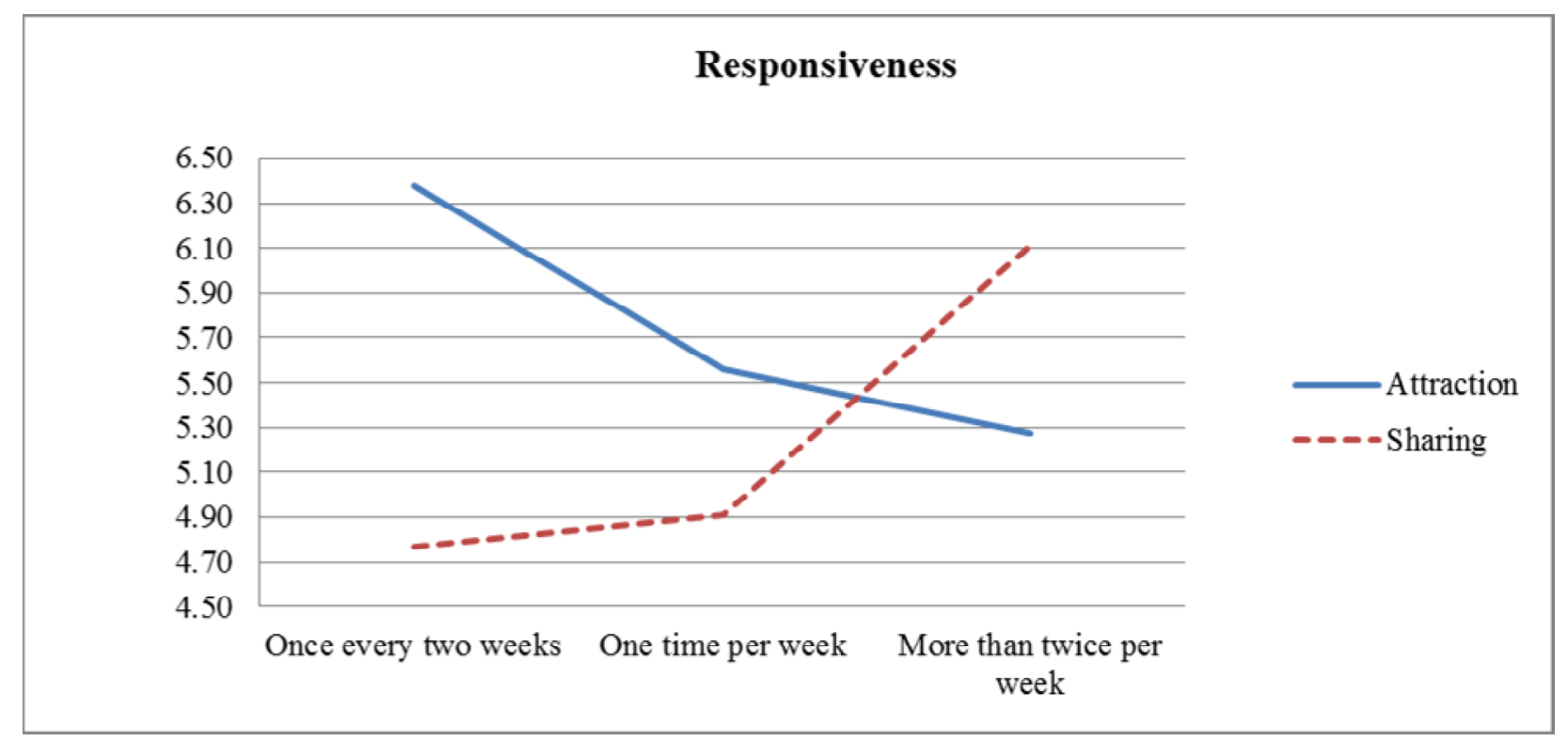

Figure 3. Differences between attraction and sharing stores: Responsiveness

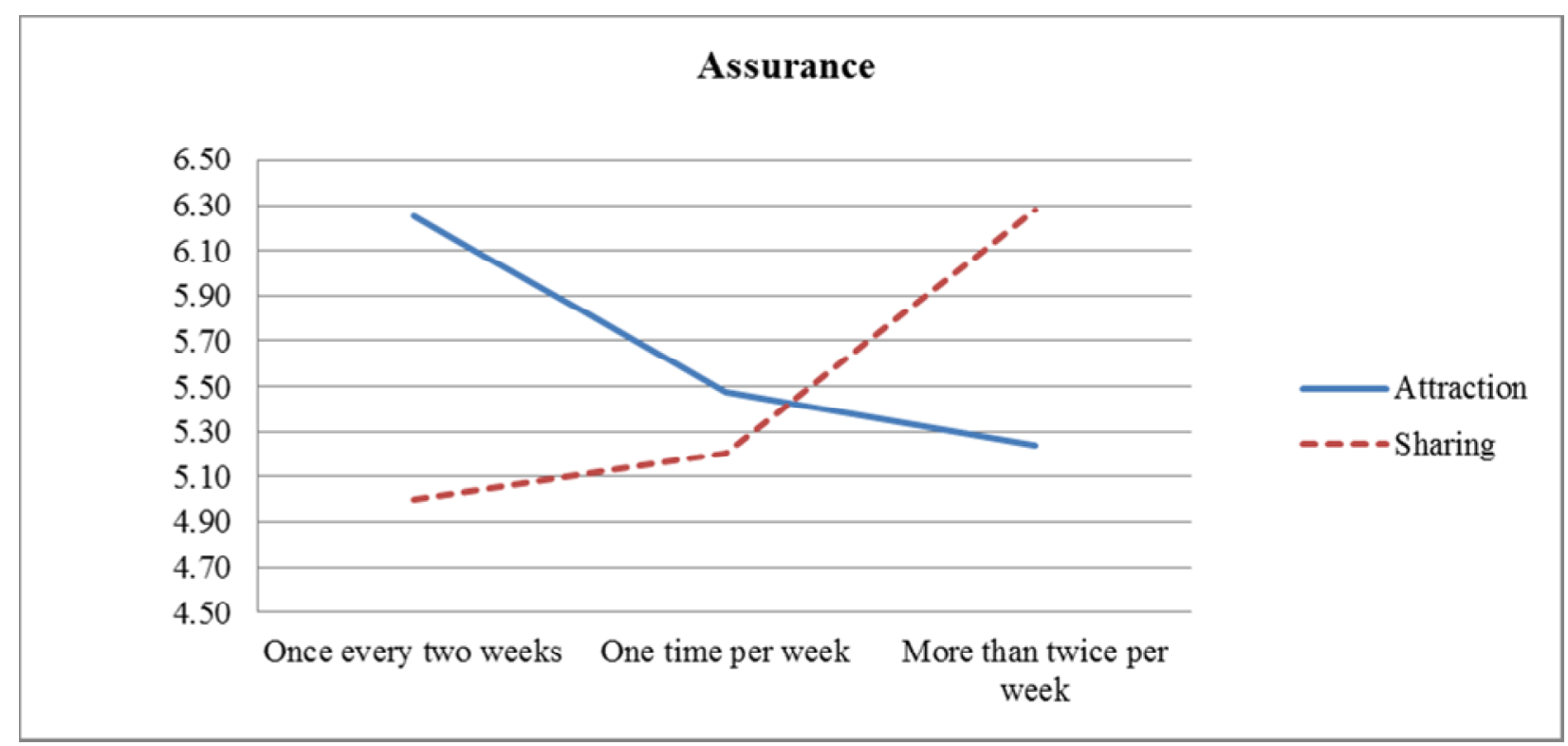

Figure 4. Differences between attraction and sharing stores: Assurance 


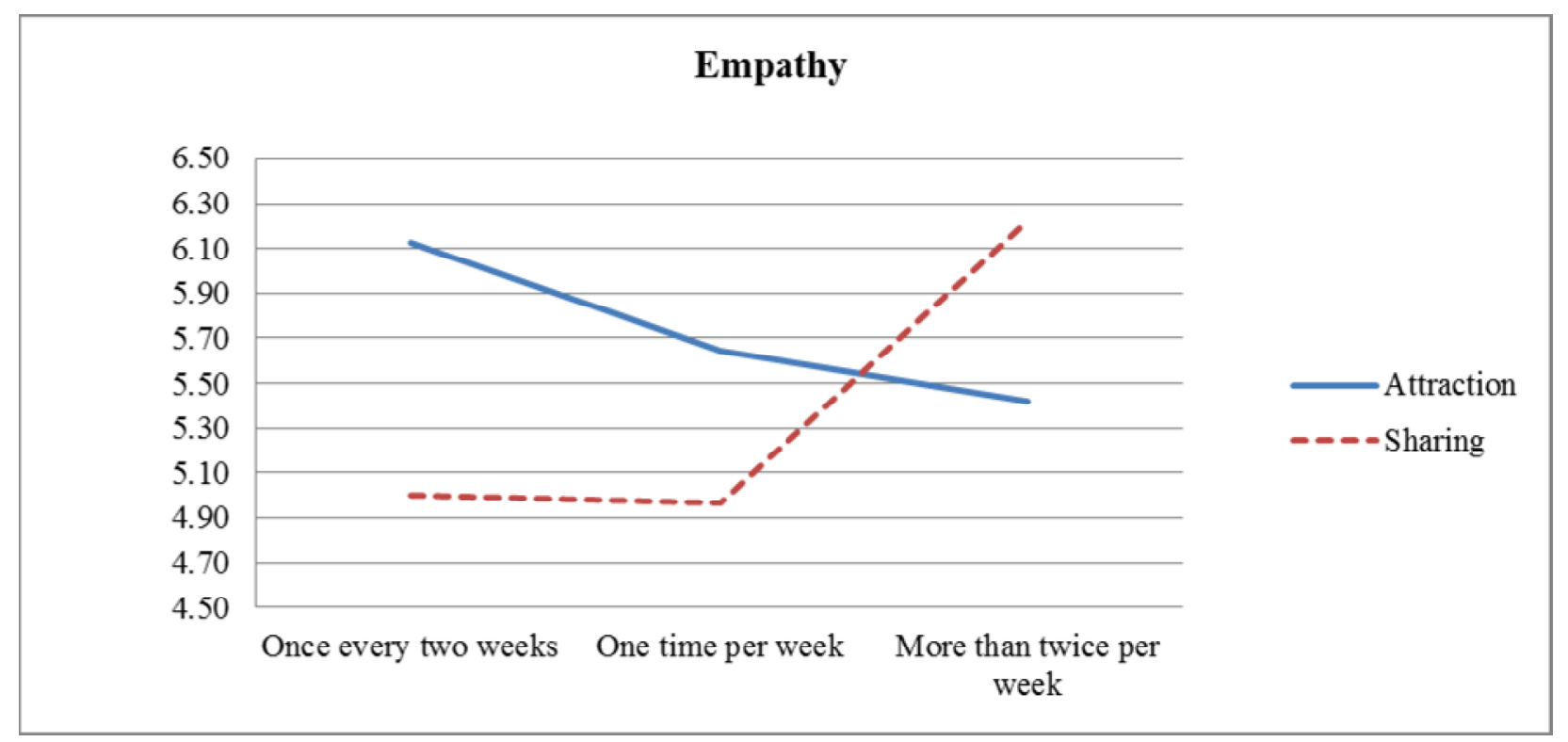

Figure 5. Differences between attraction and sharing stores: Empathy

\section{Limitations}

Limitations of the study include sample size and cell size. The current study had a $16.9 \%$ return rate based on 1,000 mailed surveys. To increase the return rate respondents were offered a chance to win a small monetary reward. The amount of the monetary reward may have been a factor in the lower response rate. In addition, K-Mart store, a discount department store, was dropped from the analysis because only two respondents indicated it was their first choice for grocery shopping. The "other" category was also dropped for the analysis. Of the 169 returned surveys 151 were useable for the analyses.

\section{Discussion and Managerial Implications}

The purpose of the current study is to provide a better understanding of the retail market structure among grocery stores (i.e., intra-type competition) by assessing cross-shopping linkages. This study approached cross-shopping from the stores' perspective. Instead of identifying differences between consumers who are or are not cross-shoppers, this study identified stores that attracted more customers from their competition making cross-shopping a store characteristic as opposed to a consumer characteristic. While previous research has identified the use of private label brands and service quality as factors associated with store loyalty; their influence on cross-shopping behavior as a store characteristic has not been addressed in the literature. This study found that cross-shopping behavior is prevalent in the grocery industry. More than $60 \%$ of respondents were found to be cross-shoppers who shop on average two different grocery stores per month. The degree of cross-shopping found in this study is supported in the literature by Uncles and Hammond's (1995) research.

By creating a cross-shopping matrix, a measure of the stores' probability for either attracting or sharing customers was developed. Attraction stores received more customers from their competition while sharing stores lost more of their customers to the competition. The grocery 
stores were then classified as either an "attraction" or "sharing" store. Use of these classifications is supported by an examination of the cross-shopping linkages. More customers identified Harris Teeter and Food Lion as a secondary store they would shop.

The statistical analysis identified several service quality variables that are significantly associated with attraction stores. No single service quality variable was found to differentiate between attraction and sharing stores. Specifically, for infrequent shoppers, attraction stores are perceived as possessing greater reliability, responsiveness, assurance, and empathy, but this perception changes as shopping frequency increases. For frequent shoppers sharing stores are perceived as possessing greater reliability, responsiveness, assurance, and empathy. The flow of customers is from stores with high service quality to stores with lower service quality. Consumers' perceptions of the quality and value of private label brands were not found to differ between attraction and sharing stores.

These findings imply that while grocery retailers need to maintain loyalty among their current customers, they also need to be aware of how they can attract their competitors' customers. Approximately $45 \%$ of respondents made eight or more grocery store trips per month which suggests there exists an opportunity to attract customers away from the competition by differentiating store offering. By understanding their attraction/sharing ratio store managers can make changes to their retail strategy that can pull consumers away from their competition. This study identifies the specific characteristics of service quality that can assist stores in capturing a greater share of their market.

In conclusion, by using the attraction/sharing classification it is possible for retailers to identify specific store characteristics that attract cross-shoppers away from their competitors. In the current study service quality was found to significantly increase the number of cross-shoppers attracted to a grocery store.

\section{References}

Aggrawal, A., Manjrekar, P., \& Aggrawal, A. (2011). Consumer Behaviour in Retail Food Patronage: A Study of Navi Mumbai. BVIMR Management Edge, 4(1), 11-14.

Ailawadi, K. L., Pauwels, K., Steenkamp, J.-B. E. M. (2008). Private-Label Use and Store Loyalty. Journal of Marketing, 72(6), 19-30. http://dx.doi.org/10.1509/jmkg.72.6.19

Baker, J., Grewal, D., Parasuraman, A. (1994). The Influence of Store Environment on Quality Inferences and Store Image. Journal of the Academy of Marketing Science, 22(4). 328-339. http://dx.doi.org/10.1177/0092070394224002

Bellizzi, J.A., Krueckeberg, H.F., Hamilton, J.R., Martin, W.S. (1981). Consumer Perceptions of National, Private, and Generic Brands. Journal of Retailing, 57(4), 56.

Bodkin, C. D., Lord, J. D. (1997). Attraction of power shopping centres. International Review of Retail. Distribution \& Consumer Research, 7(2), 93-108. http://dx.doi.org/10.1080/095939697343058

Bucklin, R. E., Lattin, J. M. (1992). A Model Product Category Competition Among Grocery 
Retailers. Journal of Retailing, 68(3), 271.

Burton, S., Lichtenstein, D. R., Netemeyer, R.G., \& Garretson, J. A. (1998). A Scale for Measuring Attitude Toward Private Label Products and an Examination of Its Psychological and Behavioral Correlates. Journal of the Academy of Marketing Science, 26(4), 293-306.

Carpenter, J. M., Balija, V. (2010). Retail format choice in the US consumer electronics market. International Journal of Retail \& Distribution Management, 38(4), 258-274. http://dx.doi.org/10.1108/09590551011032081

Carpenter, J. M., Moore, M. (2006). Consumer demographics, store attributes, and retail format choice in the US grocery market. International Journal of Retail \& Distribution Management, 34(6). 434-452. http://dx.doi.org/10.1108/09590550610667038

Cassill, N. L., Williamson, N. C. (1994). Department store cross-shoppers. Journal of Applied Business Research, 10(4). 88.

Cassill, N. L., Williamson, N. C., McEnally, M., \& Thomas, J. (1993). Intratype competition among department stores. International Review of Retail, Distribution \& Consumer Research, 3(1). 65. http://dx.doi.org/10.1080/09593969300000004

Corstjens, M., Lal, R. (2000). Building Store Loyalty Through Store Brands. Journal of Marketing Research. 37(3). 281-291. http://dx.doi.org/10.1509/jmkr.37.3.281.18781

Cort, S. G., Dominguez, L. V. (1977). Cross-Shopping and Retail Growth. Journal of Marketing Research, 14(2), 187-192. http://dx.doi.org/10.2307/3150468

Dabholkar, P. A., Thorpe, D. I., \& Rentz, J. O. (1996). A Measure of Service Quality for Retail Stores: Scale Development and Validation. Journal of the Academy of Marketing Science, 24(1), 3. http://dx.doi.org/10.1007/BF02893933

Davies, G. (1992). Positioning, image and the marketing of multiple retailers. International Review of Retail, Distribution \& Consumer Research, 2(1), 13. http://dx.doi.org/10.1080/09593969200000002

Dholakia, R. R., Uusitalo, O. (2002). Switching to electronic stores: consumer characteristics and the perception of shopping benefits. International Journal of Retail \& Distribution Management, 30(10), 459. http://dx.doi.org/10.1108/09590550210445335

Findlay, A., Sparks, L. (2008). "Switched": store-switching behaviours. International Journal of Retail \& Distribution Management, 36(5), 375-386. http://dx.doi.org/10.1108/09590550810870102

Fontenelle, M., Pereria, I. (1996). Private labels and consumer benefits: the Brazilian Experience. Advances in Consumer Research. 23(1). 97-103.

Fox, E. J., Montgomery, A. L., \& Lodish, L. M. (2004). Consumer Shopping and Spending across Retail Formats. Journal of Business, 77, S25-S60. http://dx.doi.org/10.1086/381518

Garretson, J. A., Fisher, D., \& Burton, S. (2002). Antecedents of private label attitude and 
national brand promotion attitude: similarities and difference. Journal of Retailing, 78(2), 91-99. http://dx.doi.org/10.1016/S0022-4359(02)00071-4

Hirschman, E. C. (1978). A Descriptive Theory of Retail Market Structure. Journal of Retailing, 54(4), 29.

Hirschman, E. C. (1979). Intratype Competition Among Department Stores. Journal of Retailing, 55(4), 20.

Homburg, C., Hoyer, W. D., \& Fassnacht, M. (2002). Service Orientation of a Retailer's Business Strategy: Dimensions, Antecedents, and Performance Outcomes. Journal of Marketing. 66(4). 86-101. http://dx.doi.org/10.1509/jmkg.66.4.86.18511

Hsieh, M.-F., Stiegert, K. W. (2012). Store Format Choice in Organic Food Consumption. American Journal of Agricultural Economics, 94(2), 307-313. http://dx.doi.org/10.1093/ajae/aar100

Huddleston, P., Whipple, J., Mattick, R. N., \& So Jung, L. (2009). Customer satisfaction in food retailing: comparing specialty and conventional grocery stores. International Journal of Retail \& Distribution Management, $\quad 37(1), \quad$ 63-80. http://dx.doi.org/10.1108/09590550910927162

Ingene, C. A. (1983). Intertype Competition: Restaurants versus Grocery Stores. Journal of Retailing, 59(3), 49-75.

Lesonsky, R. (2012). Are cross-shopping customers walking out of your business? The Huffington Post. February.

http://www.huffingtonpost.com/2012/02/07/are-cross-shopping-customers-walking-out_n_12 37362.html

Leszczyc, P. T. L. P., Timmermans, H. (2001). Experimental choice analysis of shopping strategies. Journal of Retailing, 77(4), 493. http://dx.doi.org/10.1016/S0022-4359(01)00054-9

Lord, J. D., Bodkin, C. D. (1996). Cross-shopping Patterns in Power Centers. Journal of Shopping Center Research, 3(1), 24.

Mahajan, Y., Sharma, S., Kerin, R. A. (1988). Assessing Market Penetration Opportunities and Saturation Potential for Multi-store, Multi-market Retailers. Journal of Retailing, 64(3), 238.

McGoldrick, P., Andre, E. (1995). The bases of shopper loyalty and promiscuity. European Journal of Marketing. 29(5). 57.

Morganosky, M. A. (1997). Format change in US grocery retailing. International Journal of $\begin{array}{llll}\text { Retail \& Distribution } & \text { Management, } & 25(6), & \end{array}$ http://dx.doi.org/10.1108/09590559710175962

Nesset, E., Nervik, B., Helgesen, Ø. (2011). Satisfaction and image as mediators of store loyalty drivers in grocery retailing. International Review of Retail, Distribution \& Consumer 
Research, 21(3), 267-292. http://dx.doi.org/10.1080/09593969.2011.588716

Ngobo, P.-V. (2011). Private label share, branding strategy and store loyalty. Journal of $\begin{array}{llll}\text { Retailing \& Consumer } \quad \text { Services, } & 18(4), & \text { 259-270. }\end{array}$ http://dx.doi.org/10.1016/j.jretconser.2010.11.007

Parasuraman, A., Zeithaml, V.A., Berry, L.L.(1988). SERVQUAL: A Multiple-Item Scale for Measuring Consumer Perceptions of Service Quality. Journal of Retailing. 64(1). 5-6.

Rhee, H., Bell, D. R. (2002). The inter-store mobility of supermarket shoppers. Journal of Retailing,78(4), 225-237. http://dx.doi.org/10.1016/S0022-4359(02)00099-4

Richardson, P. S., Jain, A. K. (1996). Household Store Brand Proneness: A Framework. Journal of Retailing,72(2), 159-185. http://dx.doi.org/10.1016/S0022-4359(96)90012-3

Ruoh-Nan, Y., Eckman, M. (2009). Are lifestyle centres unique? Consumers' perceptions across locations. International Journal of Retail \& Distribution Management, 37(1), 24-42. http://dx.doi.org/10.1108/09590550910927144

Sands, S., Oppewal, H., Beverland, M. (2009). The effects of in-store themed events on consumer store choice decisions. Journal of Retailing \& Consumer Services, 16(5), 386-395. http://dx.doi.org/10.1016/j.jretconser.2009.05.001

Seock, Y. (2009). Influence of retail store environmental cues on consumer patronage behavior across different retail store formats: an empirical analysis of US Hispanic consumers. Journal of Retailing and Consumer Services, 16(5), 329-339. http://dx.doi.org/10.1016/j.jretconser.2009.03.001

Skallerud, K., Korneliussen, T., Olsen, S. O. (2009). An examination of consumers' cross-shopping behaviour. Journal of Retailing \& Consumer Services, 16(3), 181-189. http://dx.doi.org/10.1016/j.jretconser.2008.11.012

Sullivan, P., Savitt, R. (1997). Store patronage and lifestyle factors: Implications for rural grocery retailers. International Journal of Retail \& Distribution Management, 25(11), 351. http://dx.doi.org/10.1108/09590559710192459

Uncles, M., Hammond, K. (1995). Grocery store patronage. International Review of Retail, Distribution \& Consumer Research, 5(3), 287. http://dx.doi.org/10.1080/09593969500000019

Värlander, S., Yakhlef, A.(2008). Cross-selling: The power of embodied interactions. Journal of Retailing \& Consumer Services, 15(6), 480-490. http://dx.doi.org/10.1016/j.jretconser.2008.01.003

Zameer, A., Mukherjee, D. (2011). Food and Grocery Retail: Patronage Behavior of Indian Urban Consumers. South Asian Journal of Management, 18(1), 119-148. 
Appendix 1. Survey Items and Reliabilities

\begin{tabular}{|c|c|c|c|}
\hline & & Number & Reliability \\
\hline Service Quality & Examples of survey questions & of items & $($ Cronbach's $\alpha)$ \\
\hline Tangibility & $\begin{array}{l}\text { The physical layout at my grocery store makes it easy for me to } \\
\text { find what I need; My grocery store has wide aisles }\end{array}$ & 9 & 0.91 \\
\hline Reliability & $\begin{array}{l}\text { My grocery store has merchandise available when I want it; My } \\
\text { grocery store insists on error-free sales transactions }\end{array}$ & 4 & 0.83 \\
\hline Responsiveness & $\begin{array}{l}\text { My grocery store provides its services at the time it promises to do } \\
\text { so; Employees in my grocery store provide prompt service to } \\
\text { customers }\end{array}$ & 4 & 0.87 \\
\hline Assurance & $\begin{array}{l}\text { I feel safe in my transactions with my grocery store; Employees in } \\
\text { my grocery store have the knowledge to answer customers' } \\
\text { questions }\end{array}$ & 3 & 0.9 \\
\hline Empathy & $\begin{array}{l}\text { My grocery store gives customers individual attention; When a } \\
\text { customer has a problem the employees at my grocery store show } \\
\text { sincere interest in solving it }\end{array}$ & 4 & 0.86 \\
\hline & & Number & Reliability \\
\hline Private Label & Examples of survey questions & of items & $($ Cronbach's $\alpha)$ \\
\hline Value & $\begin{array}{l}\text { I believe store brands help save me money; I believe that store } \\
\text { brands provide me with great value for the money }\end{array}$ & 4 & 0.84 \\
\hline Quality & $\begin{array}{l}\text { I believe that store brands provide me with the same quality as } \\
\text { national brands; I believe that store brands are excellent }\end{array}$ & 4 & 0.91 \\
\hline
\end{tabular}

\section{Copyright Disclaimer}

Copyright reserved by the author(s).

This article is an open-access article distributed under the terms and conditions of the Creative Commons Attribution license (http://creativecommons.org/licenses/by/3.0/). 